\title{
INFLUENCE OF $\mathrm{MnO}_{2}$ ADDITIONS TO $\mathrm{BaNd}_{2} \mathrm{Ti}_{4} \mathrm{O}_{12}$ MICROWAVE CERAMICS ON SINTERING BEHAVIOR AND DIELECTRIC PROPERTIES
}

\author{
ZI-XUAN FANG, ${ }^{\#}$ BIN TANG, MING-ZHU LONG, SHU-REN ZHANG \\ School of Microelectronics and Solid State Electronics, University of Electronic Science and Technology of China, \\ Chengdu 610054, People's Republic of China \\ National Engineering Center of Electromagnetic Radiation Control Materials, \\ University of Electronic Science and Technology of China, Jianshe Road, Chengdu 610054, PR China \\ "E-mail: tangbin@uestc.edu.cn
}

Submitted October 14, 2015; accepted March 2, 2016

\begin{abstract}
Keywords: $\mathrm{BaNd}_{2} \mathrm{Ti}_{4} \mathrm{O}_{12}$, Microwave ceramics, Dielectric properties, Microstructure
The sintering behaviors and microwave dielectric properties of $\mathrm{BaNd}_{2} \mathrm{Ti}_{4} \mathrm{O}_{12}$ (BNT4) ceramics with $x$ wt. \% $\mathrm{MnO}_{2}$ dopants $\left(x=0,1,2,3\right.$ and 4) were investigated in this paper. The tungsten-bronze type $\mathrm{BaNd}_{2} \mathrm{Ti}_{4} \mathrm{O}_{12}$ accompanied with a certain amount of $\mathrm{Ba}_{2} \mathrm{Ti}_{9} \mathrm{O}_{20}$ secondary phase was observed for all Mn doped compositions when samples were sintered at $1300^{\circ} \mathrm{C}$. Manganese substitution for Ti caused a decrease of the lattice parameters, and the addition of $\mathrm{MnO}_{2}$ effectively improved the densification and lowered the sintering temperature of ceramics, which was closely related to the liquid phase sintering mechanism. The microstructure was homogeneous fine grained when x equaled to 3 . At last, the $\mathrm{BaNd}_{2} \mathrm{Ti}_{4} \mathrm{O}_{12}$ with $3.0 \mathrm{wt}$. \% $\mathrm{MnO}_{2}$ dopants well-sintered at $1300^{\circ} \mathrm{C}$ for $1 \mathrm{~h}$ had good microwave dielectric properties of $\varepsilon_{r}=90.2, Q \times f=5225 \mathrm{GHz}$ and $\tau_{f}=9.7 \mathrm{ppm} \cdot{ }^{\circ} \mathrm{C}^{-1}$.
\end{abstract}

\section{INTRODUCTION}

With the explosively increasing demand in the wireless communication systems and consumer electronic market, the microwave dielectric ceramics have been extensively investigated for microwave device applications, such as resonators, filters, and oscillators [1, 2]. Among tremendous amounts of microwave dielectric materials, $\mathrm{BaO}-\mathrm{Ln}_{2} \mathrm{O}_{3}-\mathrm{TiO}_{2}(\mathrm{Ln}=\mathrm{Nd}, \mathrm{Sm}$ and $\mathrm{La})$ are attracting much attention because of their high dielectric constants $\left(\varepsilon_{r}=80-110\right)$, high quality factors $(Q \times f=1800 \sim 10000 \mathrm{GHz})$ and tunable temperature coefficients of resonant frequency $\left(\tau_{f}\right)$ [3]. Ceramics, with $\mathrm{BaO}: \mathrm{Nd}_{2} \mathrm{O}_{3}: \mathrm{TiO}_{2}$ of around $1: 1: 4$ and a high dielectric constant $\left(\varepsilon_{r}=70-90\right)$, have been commonly applied in mobile telephone systems [4]. As reported by previous researches $[4,5]$, the chemical compound $\mathrm{BaNd}_{2} \mathrm{Ti}_{4} \mathrm{O}_{12}$ has emerged as a promising microwave ceramic due to a good combination of a high dielectric constant $\left(\varepsilon_{r} \sim 84\right)$ and a high quality factor $(Q \times f \sim 7800 \mathrm{GHz})$. But the large $\tau_{f}$ value of $94 \mathrm{ppm} \cdot{ }^{\circ} \mathrm{C}^{-1}$ limits its practical applications as dielectric resonator.

Fortunately, recent studies reported that $\mathrm{Mn}^{4+}$ or $\mathrm{Mn}^{2+}$ ions had positive effect on the dielectric properties of various ceramics. The $\mathrm{MnO}_{2}$ is an effective sintering aid to enhance densification and reduce dielectric loss in $\mathrm{Ba}_{4.2} \mathrm{Nd}_{9.2} \mathrm{Ti}_{18} \mathrm{O}_{54}-\mathrm{NdAlO}_{3}$ and $\mathrm{K}_{0.5} \mathrm{Na}_{0.5} \mathrm{Nb}_{0.92} \mathrm{Sb}_{0.08} \mathrm{O}_{3}$ system $[6,7]$. As the critical concentration ( $\geq 43 \mathrm{~mol}$. \%) of $\mathrm{MnCO}_{3}$ additives was reached, Lee et al. [8]. revealed that the microwave dielectric properties of $\mathrm{BaO}-\left(\mathrm{Nd}_{0.7} \mathrm{Sm}_{0.3}\right)_{2} \mathrm{O}_{3}-4 \mathrm{TiO}_{2}$ were significantly improved owing to the formation of a new $\mathrm{BaNd}_{2} \mathrm{Ti}_{4} \mathrm{O}_{12}$ phase and a Mn-rich phase. Varma et al. [9]. reported that an improved quality factor of $\mathrm{Ba}\left(\mathrm{Zn}_{1 / 3} \mathrm{Ta}_{2 / 3}\right) \mathrm{O}_{3}$ ceramics was obtained with a small amount of $\mathrm{MnO}_{2}$. Cai et al. [10] studied the dielectric properties of $\mathrm{BaZr}_{0.2} \mathrm{Ti}_{0.8} \mathrm{O}_{3}$ ceramics doped by various concentration of $\mathrm{MnO}_{2}$. It was found that $\mathrm{Mn}^{4+}$ ions had entered the unit cell occupying the $\mathrm{B}$ sites of the perovskite structure and with increasing $\mathrm{MnO}_{2}$ addition, the dielectric loss of $\mathrm{BaZr}_{0.2} \mathrm{Ti}_{0.8} \mathrm{O}_{3}$ ceramics could be effectively reduced.

So far, many efforts have been made to improve the comprehensive properties of $\mathrm{BaNd}_{2} \mathrm{Ti}_{4} \mathrm{O}_{12}$ ceramics by doping various additives. $\mathrm{CuO}$ can effectively reduce the sintering temperature with a small amount of addition, so that the negative impact of sintering aid on dielectric properties such as quality factor can be minimized [5]. It was also reported by Chen et al. that an increasing dielectric constant and a near-zero $\tau_{f}$ value were obtained by doping $\mathrm{Bi}_{4} \mathrm{~B}_{2} \mathrm{O}_{9}$ to BNT4 ceramics [11]. However, $\mathrm{MnO}_{2}$, as an effective aid to many material systems, has not been systematically researched in BNT4 ceramics. In our present work, the effects of various contents of $\mathrm{MnO}_{2}$ additives on microstructure, sintering behavior and microwave dielectric properties of $\mathrm{BaNd}_{2} \mathrm{Ti}_{4} \mathrm{O}_{12}$ were investigated in detail. 


\section{EXPERIMENTAL}

The $\mathrm{BaNd}_{2} \mathrm{Ti}_{4} \mathrm{O}_{12}$ microwave ceramics were synthesized by the conventional solid-state ceramic route. High-purity powders of $\mathrm{BaCO}_{3}(\geq 99.9 \%$, Mianyang Yuanda New Materials Co., Ltd, Mianyang, China), $\mathrm{Nd}_{2} \mathrm{O}_{3}$ (99.8 \%, Gansu Rare-earth New Materials Co., Ltd, Baiyin, China), $\mathrm{MnO}_{2}(99.8 \%$, Xiantao ZhongXing Electric Co., Ltd, Xiantao, China) and $\mathrm{TiO}_{2}$ (99.9 \%, Xiantao ZhongXing Electric Co., Ltd, Xiantao, China) were used as the starting materials. The raw oxide materials were weighed according to the stoichiometry proportions and ball milled in deionized water medium for $5 \mathrm{~h}$ in nylon jars using zirconia balls. The mixture was dried and calcined at $1100^{\circ} \mathrm{C}$ for $4 \mathrm{~h}$. Then the calcined BNT4 powders were re-milled respectively with $x$ wt. $\% \mathrm{MnO}_{2}(x=1,2,3$ and 4) powders for $4 \mathrm{~h}$. After drying, the powder was mixed with 5 wt. \% polyvinyl alcohol (PVA) binder, then dried and ground well. The obtained fine powder was axially pressed into cylindrical disks with the thickness of $4 \mathrm{~mm}$ and $11 \mathrm{~mm}$ in diameter under a pressure of $25 \mathrm{MPa}$. These pellets were sintered at different sintering temperatures from 1200 to $1350^{\circ} \mathrm{C}$ for $1 \mathrm{~h}$ in air.

After sintering, the bulk densities of the samples were measured using the Archimedes method. The phase composition and crystal structure of the ceramics were examined by X-ray diffraction technique using $\mathrm{CuKa}$ radiation (DX-1000 CSC, Japan). Scanning electron microscopy (SEM) (JSM-6460LV, Jeol, Tokyo, Japan) was employed to study the surface morphology of the specimens. The microwave dielectric properties were measured by a Vector Network Analyzer (E5071C, Agilent Technologies) and a temperature chamber (DELTA 9023, Delta Design, USA.). In addition, the temperature coefficients of resonant frequency $\tau_{f}$ values were calculated by the equation: $\tau_{f}=\left(f_{t_{2}}-f_{t_{1}}\right) /\left[f_{t_{1}} \times\right.$ $\times\left(t_{2}-t_{1}\right)$ ], where $f_{t_{1}}$ and $f_{t_{2}}$, were the resonant frequencies at the measuring temperature $t_{1}\left(25^{\circ} \mathrm{C}\right)$ and $t_{2}\left(85^{\circ} \mathrm{C}\right)$, respectively.

\section{RESULTS AND DISCUSSION}

Figure 1a shows the XRD patterns of $\mathrm{BaNd}_{2} \mathrm{Ti}_{4} \mathrm{O}_{12}$ ceramics with different $x$ value sintered at $1300^{\circ} \mathrm{C}$ for $1 \mathrm{~h}$ in air. For the sintered samples of all compositions, the main phase was identified as orthorhombic tungstenbronze type $\mathrm{BaNd}_{2} \mathrm{Ti}_{4} \mathrm{O}_{12}$ (JCPDS Card No. 44-0061). However, it was also observed that a certain amount of $\mathrm{Ba}_{2} \mathrm{Ti}_{9} \mathrm{O}_{20}$ secondary phase (JCPDS Card No.76-1538) appeared with $x \geq 1$ wt. \%. Obviously, with 1 wt. \% $\mathrm{MnO}_{2}$ addition, the diffraction peak of the main crystal phase $\mathrm{BaNd}_{2} \mathrm{Ti}_{4} \mathrm{O}_{12}$ showed the strongest intensity, which indicated that $\mathrm{BaNd}_{2} \mathrm{Ti}_{4} \mathrm{O}_{12}$ crystals grew better than in other compositions. As the amount of $\mathrm{MnO}_{2}$ was increased, the diffraction intensity of $\mathrm{BaNd}_{2} \mathrm{Ti}_{4} \mathrm{O}_{12}$ phase weakened sharply. Especially for the composition with $x=4$ wt. $\%$, the diffraction intensity of its main phase was nearly three fourths of that for the composition with $x=1 \mathrm{wt}$. \%. In order to clarify the peaks of the secondary phase, the amplified profiles (a) of strongest characteristic peak (around the $2 \theta$ angle of $28.9^{\circ}$ ) for the $\mathrm{Ba}_{2} \mathrm{Ti}_{9} \mathrm{O}_{20}$ phase of the corresponding specimens are shown in Figure 1b. As displayed in Figure 1b, it was clear that the amount of $\mathrm{Ba}_{2} \mathrm{Ti}_{9} \mathrm{O}_{20}$ phase remained almost the same accompanied by the decreasing intensity of main phase with an increase of $\mathrm{MnO}_{2}$ content. As reported in previous researches $[12,13]$, the anorthic $\mathrm{Ba}_{2} \mathrm{Ti}_{9} \mathrm{O}_{20}$ secondary phase was frequently found in variously doped $\mathrm{BaO}-\mathrm{Ln}_{2} \mathrm{O}_{3}-\mathrm{TiO}_{2}$ ceramics even in the pure $\mathrm{BaO}-\mathrm{Ln}_{2} \mathrm{O}_{3}-\mathrm{TiO}_{2}$ system ceramic. Fortunately, under our experimental conditions, no other impurity phases were detected in the pure BNT4 ceramics ( $x=0$ wt. \%). Finally, it was known that the decrease of main crystal phase content would have a significant influence on the dielectric properties of microwave ceramics.

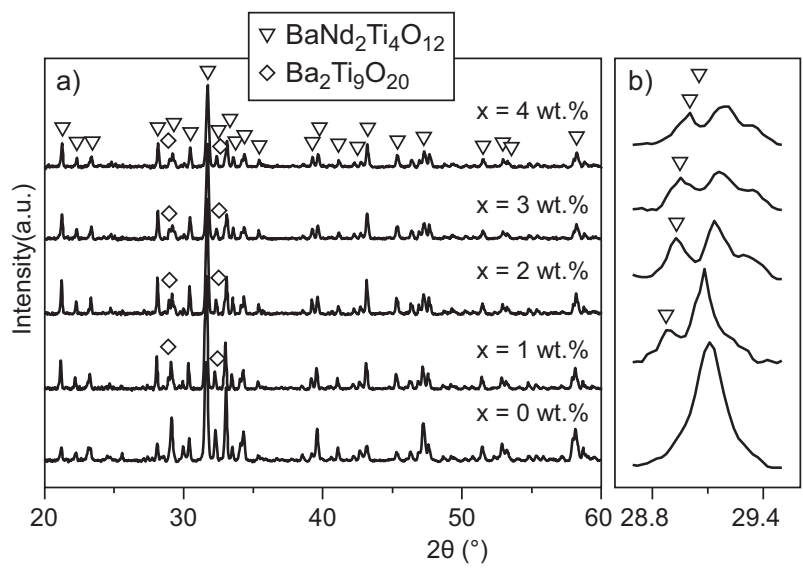

Figure 1. XRD patterns of $\mathrm{BaNd}_{2} \mathrm{Ti}_{4} \mathrm{O}_{12}$ samples with different $x$ value sintered at $1300^{\circ} \mathrm{C}$ for 1 hour in air (a); the strongest peak (around the $2 \theta$ angle of $28.9^{\circ}$ ) for the $\mathrm{Ba}_{2} \mathrm{Ti}_{9} \mathrm{O}_{20}$ phase of the corresponding specimens (b).

It was also found from Figure 1a and Figure $1 \mathrm{~b}$ that there was a movement of the peaks towards higher degree for $\mathrm{BaNd}_{2} \mathrm{Ti}_{4} \mathrm{O}_{12}$ phase indicating smaller ionic substitution according to Bragg's law. Hence the lattice parameters and unit cell volume for the solid solution $\mathrm{BaNd}_{2} \mathrm{Ti}_{4} \mathrm{O}_{12}$ phase were calculated and the results are shown in Figure 2. With increasing the doping amount of $\mathrm{MnO}_{2}$ from 1 wt. $\%$ to 4 wt. $\%$, the a-axis, b-axis and c-axis were dropped, and thus the unit cell volume also declined. It was deduced that $\mathrm{Mn}^{4+}$ ions inclined to partially substitute for $\mathrm{Ti}^{4+}$ of $\mathrm{BaNd}_{2} \mathrm{Ti}_{4} \mathrm{O}_{12}$ ceramics and form a solid solution, since the ionic radius of $\mathrm{Mn}^{4+}$ $(0.60 \AA)$ is close to that of $\mathrm{Ti}^{4+}(0.68 \AA)$ and much smaller than that of $\mathrm{Ba}^{2+}(1.34 \AA)$ and $\mathrm{Nd}^{3+}(1.04 \AA)$ [14]. It was reported that $\mathrm{Mn}^{4+}$ had entered the unit cell occupying the Ti sites of the perovskite structure in $\mathrm{BaZr}_{0.2} \mathrm{Ti}_{0.8} \mathrm{O}_{3}$ ceramics [10] and would exactly locate at the Ti site 
in manganese doped $\mathrm{PbTiO}_{3}$ ceramics [15]. From the continuous downward trend of lattice parameters as shown in Figure 2, it could be concluded that the amount of $\mathrm{Ti}^{4+}$ substituted by $\mathrm{Mn}^{4+}$ increased with increasing $\mathrm{MnO}_{2}$ dopants and this substitution could cause the shrinkage of the crystal lattice for $\mathrm{BaNd}_{2} \mathrm{Ti}_{4} \mathrm{O}_{12}$ ceramics. Moreover, since the part of $\mathrm{Mn}^{4+}$ entered into the crystal lattice would cause lattice distortion [16], the difference of their ionic radius also resulted in the lattice distortion.

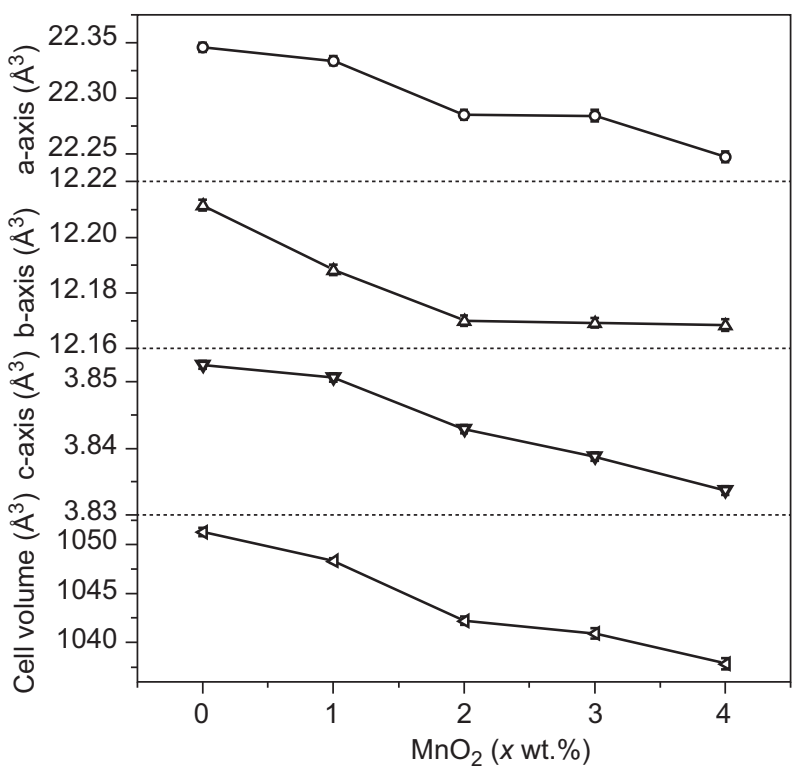

Figure 2. The $\mathrm{MnO}_{2}$ doping dependence of the refined lattice parameters of $\mathrm{BaNd}_{2} \mathrm{Ti}_{4} \mathrm{O}_{12}$ ceramics sintered at $1300^{\circ} \mathrm{C}$ for $1 \mathrm{~h}$ in air.

Figure 3 shows the $\mathrm{SEM}$ micrographs of $\mathrm{BaNd}_{2} \mathrm{Ti}_{4} \mathrm{O}_{12}$ ceramics with various amounts of $\mathrm{MnO}_{2}$ addition sintered at $1300^{\circ} \mathrm{C}$ for $1 \mathrm{~h}$ in air. We could see that the whole grains were long-column-like For the Mn-free samples (Figure 3a), the ceramic showed a porous and inhomogeneous microstructure, and had a grain size of 2 to $3 \mu \mathrm{m}$. For the samples doped with $\mathrm{Mn}$ additives (Figure $4 b-e$ ), the grain sizes in the range of 5 to $9 \mu \mathrm{m}$ are much larger than those of Mn-free samples and it was evident that the grains gradually became larger and larger. And specimens with Mn additives presented compact microstructure with almost no pores, indicating that BNT4 samples with high densification were obtained. Increase of $\mathrm{MnO}_{2}$ additive content had insignificant effect on the morphology of grains. But by careful observation of the microstructure, there indeed existed slight changes in the microstructure of grains. While increasing $\mathrm{MnO}_{2}$ content up to 3 wt. \%, the microstructures of BNT4 ceramics became more and more homogeneous, especially for the composition of 3 wt. $\%$, the homogeneous fine grained microstructure was observed and the crystal grain size was in the range of $5 \mu \mathrm{m}$. Samples with 4 wt. $\% \mathrm{MnO}_{2}$ dopants also showed relatively uniform microstructure. But as directed by the white arrows in Figure $3 e$, it could be seen that the grain edge and corner became blurred when compared with those of other compositions.

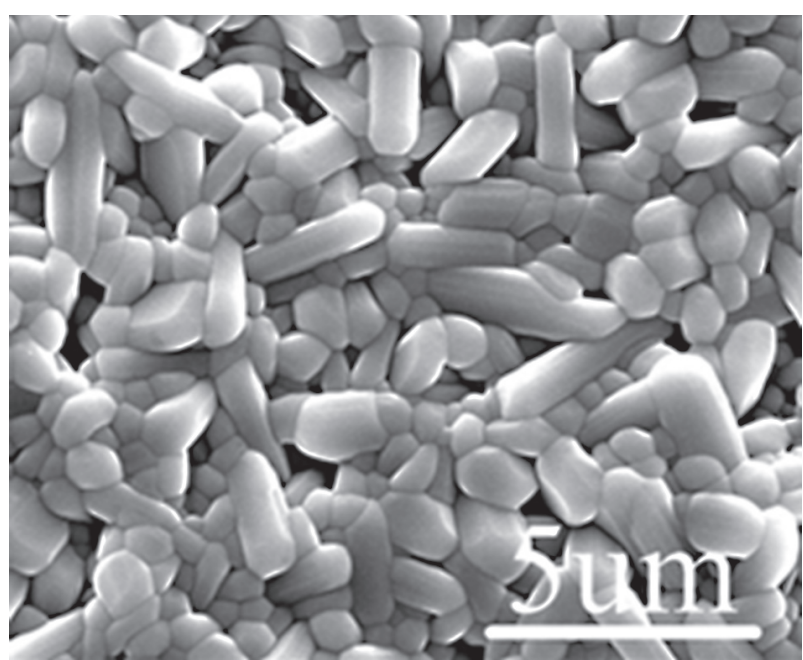

a)

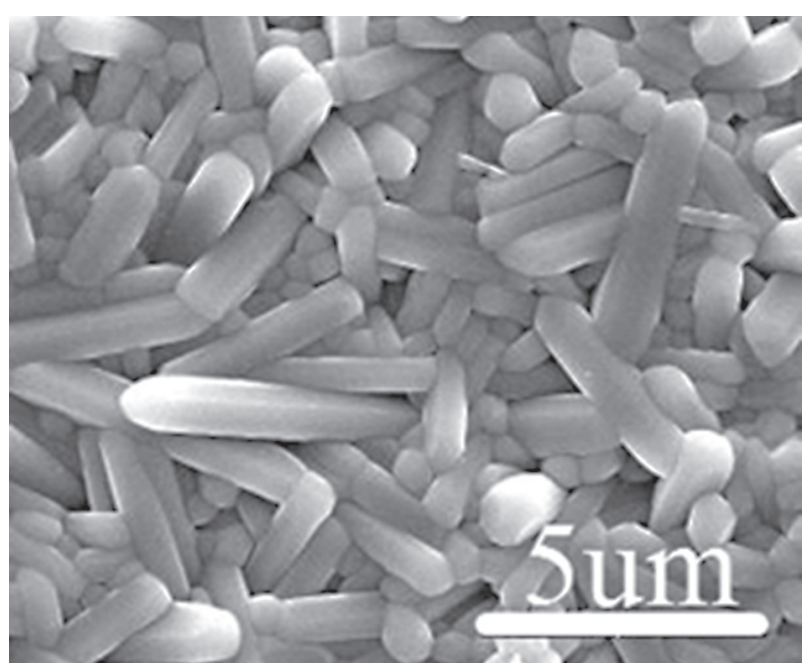

b)

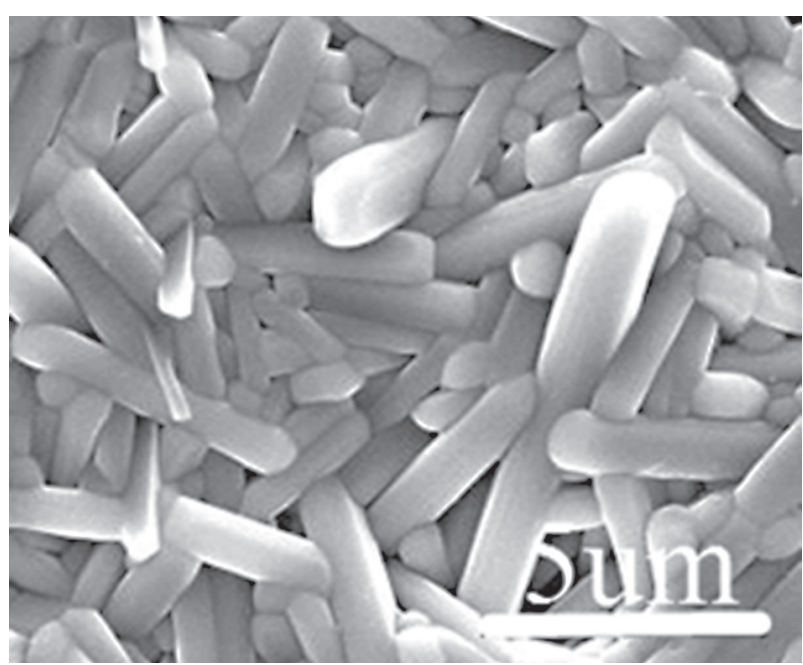

c)

Figure 3. The SEM micrographs of $\mathrm{BaNd}_{2} \mathrm{Ti}_{4} \mathrm{O}_{12}$ ceramics with different $x$ value sintered at $1300^{\circ} \mathrm{C}$ for 1 hour in air. 


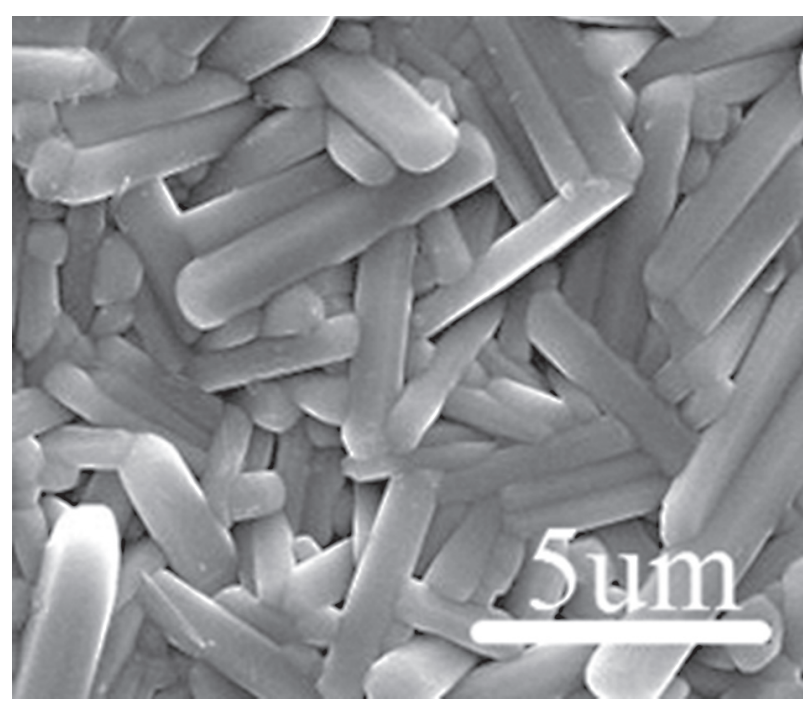

d)

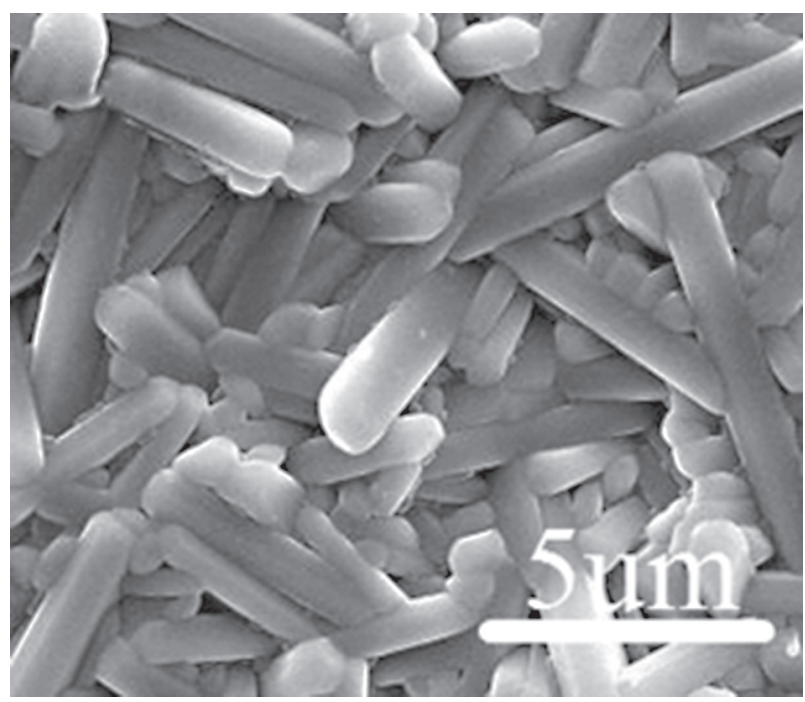

e)

Figure 3. The SEM micrographs of $\mathrm{BaNd}_{2} \mathrm{Ti}_{4} \mathrm{O}_{12}$ ceramics with different $x$ value sintered at $1300^{\circ} \mathrm{C}$ for 1 hour in air.

Figure 4 depicts the relative density of $\mathrm{BaNd}_{2} \mathrm{Ti}_{4} \mathrm{O}_{12}$ ceramics with different $\mathrm{MnO}_{2}$ addition content as a function of sintering temperature in air. It was obvious that as $\mathrm{MnO}_{2}$ content varied from 0 wt. $\%$ to 2 wt. $\%$, the relative density of samples with each fixed $\mathrm{MnO}_{2}$ dopant maintained an upward trend due to the improvement of densification with increasing sintering temperature up to $1350^{\circ} \mathrm{C}$. Meanwhile, in the relatively low sintering temperature range $1200-1300^{\circ} \mathrm{C}$, the relative density was also strongly influenced by $\mathrm{MnO}_{2}$ content. For example, as the $\mathrm{MnO}_{2}$ content approached 3 wt. \%, it can be seen that the relative density of BNT4 ceramics went up to the maximum value at $1300^{\circ} \mathrm{C}$ which was attributed to the improvement of densification, and thereafter decreased with further increase of sintering temperature. When the $\mathrm{MnO}_{2}$ addition content was raised to $4 \mathrm{wt}$. $\%$, the optimal sintering temperature can be effectively lowered to $1250^{\circ} \mathrm{C}$. Also, in the low sintering temperature range of $1250^{\circ} \mathrm{C}$ to $1300^{\circ} \mathrm{C}$, especially for the point of $1250^{\circ} \mathrm{C}$, relative densities of $\mathrm{Mn}$ doped samples were significantly improved and much larger than that of Mn-free specimens. Laffez et al. [13] reported that $\mathrm{MnO}_{2}$ dopants could form liquid phase in $\mathrm{Ba}_{6-x}\left(\mathrm{Sm}_{1-y} \mathrm{Nd}_{y}\right)_{8+2 x / 3} \mathrm{Ti}_{18} \mathrm{O}_{54}$ oxides. Appel et al. [17] revealed that $\mathrm{Mn}$ doping promoted the propagation of ions because of the formation of Mn containing liquid phase at a lower sintering temperature of $1350^{\circ} \mathrm{C}$. And as marked by white arrows in Figure 3d, the grains with blurred edge or corner may be related to the low melting compounds or liquid phase. Hence, by analogy, the sintering behavior of our experiment should be closely related to $\mathrm{Mn}$ doping causing the formation of Mn containing liquid phase. As previously reported [5], the optimal sintering temperature of pure $\mathrm{BaNd}_{2} \mathrm{Ti}_{4} \mathrm{O}_{12}$ ceramics was generally higher than $1350^{\circ} \mathrm{C}$. Therefore, when comparing our results with previous studies, we could clearly see that the adequate Mn doping would effectively reduce the sintering temperature and the BNT4 ceramics could be well-sintered at the temperature lower than $1300^{\circ} \mathrm{C}$. And at low sintering temperature, relative densities of BNT4 samples could be significantly improved by the adding $\mathrm{MnO}_{2}$.

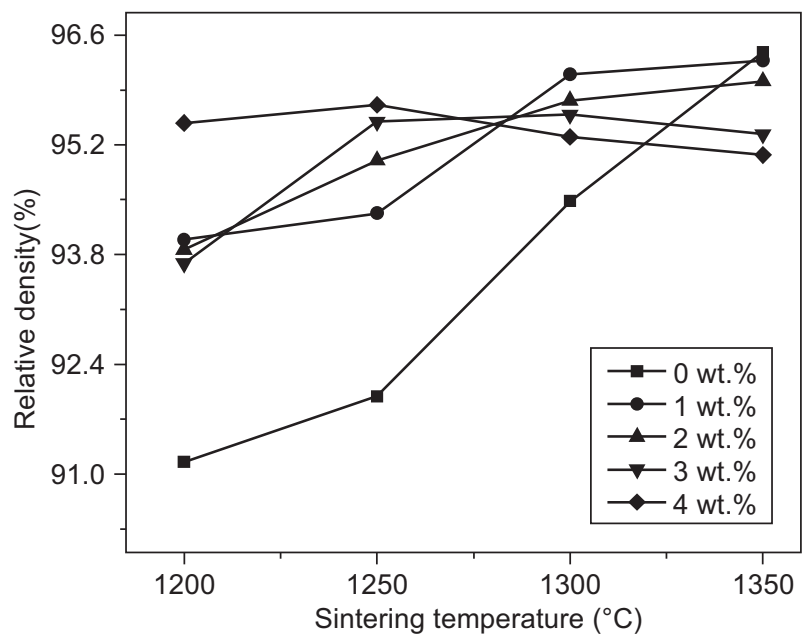

Figure 4. The relative density of $\mathrm{BaNd}_{2} \mathrm{Ti}_{4} \mathrm{O}_{12}$ ceramics with different $x$ value as a function of sintering

Figure 5 shows the dielectric constant of $\mathrm{BaNd}_{2} \mathrm{Ti}_{4} \mathrm{O}_{12}$ ceramics with different $\mathrm{MnO}_{2}$ doping content as a function of sintering temperature in air. The dielectric constant at microwave frequencies is dependent on the relative density, secondary phase, microstructure and polarizability $[18,19]$. With $\mathrm{MnO}_{2}$ contents varying from 0 wt. $\%$ to 3 wt. $\%$, variation of the dielectric constant shown in Figure 5 was almost in accordance with that of the relative density presented in Figure 4 because both density and dielectric constant are strongly influenced by the fraction of pores (density $\approx 0$ and $\left.\varepsilon_{r} \approx 1\right)$. When $x$ equaled to $4 \mathrm{wt}$. $\%$, the $\varepsilon_{r}$ value increased first, reached a maximum value at $1300^{\circ} \mathrm{C}$ and then 
decreased. The increase of $\varepsilon_{r}$ value for specimens with $x=4$ wt. $\%$ sintered below $1300^{\circ} \mathrm{C}$ was mainly attributed to the improvement of densification. As confirmed by the analysis of changing density, samples with 4 wt. $\% \mathrm{MnO}_{2}$ could be well-sintered at a much lower temperature of $1250^{\circ} \mathrm{C}$. Therefore, it was reasonable to understand that the dielectric constant began to drop at the temperature above $1300^{\circ} \mathrm{C}$ which may be resulted from excessively high sintering temperature. Furthermore, the dielectric constant was strongly affected by the variation of $\mathrm{MnO}_{2}$ dopants. When the amounts of $\mathrm{MnO}_{2}$ dopants varied from 0 wt. $\%$ to 4 wt. $\%$, the maximum $\varepsilon_{r}$ value of every composition was raised from 75.2 to 93.0. First of all, the enhancement of $\varepsilon_{r}$ could be attributed to the facts that uniform and oligoporous microstructures could be obtained for the compositions with 3 wt. \% and 4 wt. \% $\mathrm{MnO}_{2}$, as shown in Figure 3d and Figure 3e. What's more, especially in the low sintering temperature of $1250^{\circ} \mathrm{C}$ to $1300^{\circ} \mathrm{C}$, the dielectric constant was remarkably enhanced to the largest value of 93.0 which should primarily be contributed to the significant improvement of relative densities (from $91.2 \%$ to $96.1 \%$ ). From another point of view, the number of polarizable particles per unit volume was increased due to the shrinkage of the cell volume, leading to the enhancement of polarizability [20-22]. Therefore, the successive shrinkage of the cell volumes caused by $\mathrm{Mn}^{4+}$ substitution might be responsible for the continuous improvement of dielectric constant with 1 wt. $\% \leq x \leq 4$ wt. $\%$. But for the Mn-doped BNT4 ceramics, our results indicated that the secondary phase failed to affect the dielectric constant although a certain amount of $\mathrm{Ba}_{2} \mathrm{Ti}_{9} \mathrm{O}_{20}$ phase with relatively low $\varepsilon_{r}$ value of 39.8 [23] were detected which may be contributed to the reason that its negative effect was compensated by the positive factors mentioned above. Eventually, it was obtained that a maximum $\varepsilon_{r}(\sim 93)$ of BNT4 ceramics with 3 wt. $\% \mathrm{MnO}_{2}$ was much higher

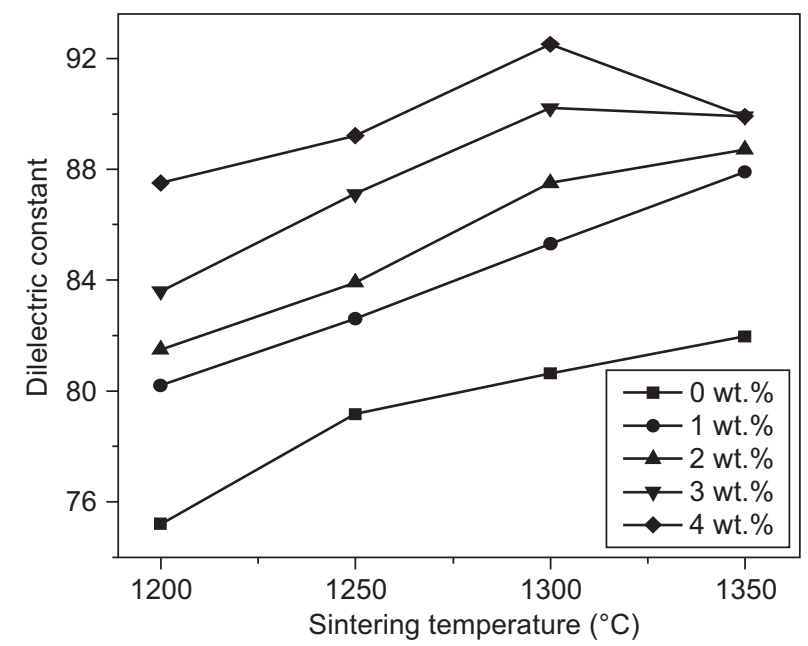

Figure 5. The dielectric constant of $\mathrm{BaNd}_{2} \mathrm{Ti}_{4} \mathrm{O}_{12}$ ceramics with different $x$ value as a function of sintering temperature for 1 hour in air. than that of the pure BNT4 ceramics $(\sim 75)$, which was similar to that of $\mathrm{Bi}_{2} \mathrm{O}_{3}$-doped $\mathrm{BNT} 4$ ceramics [12] and $\mathrm{Bi}_{4} \mathrm{~B}_{2} \mathrm{O}_{9}$-doped $\mathrm{BNT} 4$ ceramics [11].

The variation of $Q \times f$ values for $\mathrm{BaNd}_{2} \mathrm{Ti}_{4} \mathrm{O}_{12}$ ceramic samples sintered in air at different sintering temperatures as a function of different $x$ value are presented in Figure 6. It was observed that the $Q \times f$ value was increased till $1350^{\circ} \mathrm{C}$ with $x \leq 2$ wt. $\%$. For the compositions with 3 wt. $\%$ and 4 wt. $\% \mathrm{MnO}_{2}$, the $Q \times f$ value reached its maximum value at a sintering temperature of $1300^{\circ} \mathrm{C}$ and then started to decline. The $Q \times f$ value was affected by many factors, such as pores, structure defects, densification, phase compositions, micromorphology and lattice distortion [24-26]. With increasing $x$ value from 0 wt. $\%$ to 4 wt. $\%$, the overall $Q \times f$ values showed a downward trend from 9367 to $4658 \mathrm{GHz}$. As confirmed by XRD analysis in Figure 1, the intensity of main phase decreased sharply, and therefore the decrease of the $Q \times f$ value was mainly caused by the progressively deteriorated $\mathrm{BaNd}_{2} \mathrm{Ti}_{4} \mathrm{O}_{12}$ phase. A similar result was observed in the experiment conducted by Laffez et al. They found that $\mathrm{MnO}_{2}$ dopants could form liquid phase in $\mathrm{Ba}_{6-\mathrm{x}}\left(\mathrm{Sm}_{1-y} \mathrm{Nd}_{y}\right)_{8+2 x / 3} \mathrm{Ti}_{18} \mathrm{O}_{54}$ oxides which was probably the ferroelectric or semiconductor with high dielectric loss [13], and the $Q \times f$ values of samples decreased. In the end, the lattice distortion caused by manganese substitution may also be responsible to the consecutive decrease of $Q \times f$ values.

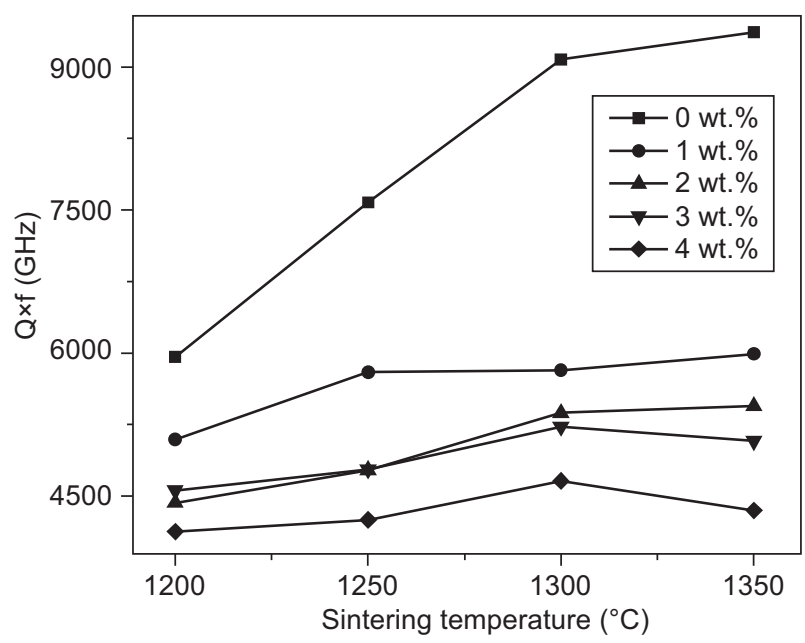

Figure 6. The quality factor of $\mathrm{BaNd}_{2} \mathrm{Ti}_{4} \mathrm{O}_{12}$ ceramics with different $x$ value as a function of sintering temperature

Figure 7 shows the temperature coefficient of the resonant frequency of $\mathrm{BaNd}_{2} \mathrm{Ti}_{4} \mathrm{O}_{12}$ ceramics sintered in air at different temperatures as a function of the $\mathrm{MnO}_{2}$ amounts. The $\tau_{f}$ values did not change considerably with 1 wt. $\% \leq x \leq 4$ wt. $\%$ and the overall $\tau_{f}$ values maintained an upward trend, which were between 7.7 and $14.2 \mathrm{ppm} \cdot{ }^{\circ} \mathrm{C}^{-1}$. It was remarkable that the $\tau_{f}$ values of $\mathrm{MnO}_{2}$ added specimens were much lower than that of 
pure BNT4 ceramics. In general, the $\tau_{f}$ is related to the composition, secondary phases [19], and crystal lattice [27]. The $\mathrm{Ba}_{2} \mathrm{Ti}_{9} \mathrm{O}_{20}$ secondary phase was observed for all $\mathrm{MnO}_{2}$ added samples. Hence, the appearance of $\mathrm{Ba}_{2} \mathrm{Ti}_{9} \mathrm{O}_{20}$ probably contributed to the relatively lower $\tau_{f}$ values due to its much lower $\tau_{f}$ value of $2 \mathrm{ppm} \cdot{ }^{\circ} \mathrm{C}^{-1}[23]$ when compared with the existed literature for $\mathrm{BaNd}_{2} \mathrm{Ti}_{4} \mathrm{O}_{12}$ $\left(\tau_{f}=94 \mathrm{ppm} \cdot{ }^{\circ} \mathrm{C}^{-1}\right)$. Raising the amount of $\mathrm{MnO}_{2}$ led to an increase of $\tau_{f}$ value. Kim et al. [28]. discovered that the $\tau_{f}$ of tungsten bronze-type structure was closely related to the extent of the tilting and distortion of the octahedron. When combining the analysis with Figure 2, doping $\mathrm{MnO}_{2}$ could have an influence on the tilting and distortion of the octahedron in BNT4 ceramics. Therefore, it was reasonable to believe that $\tau_{f}$ value would move towards the positive direction when the BNT4 ceramics are doped with increasing content of $\mathrm{MnO}_{2}$.

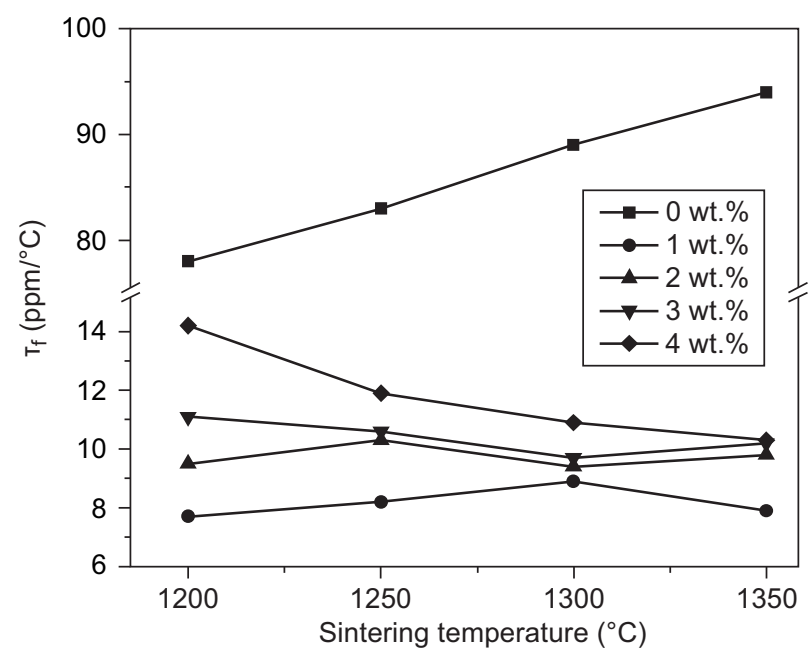

Figure 7. The temperature coefficients of resonant frequency of $\mathrm{BaNd}_{2} \mathrm{Ti}_{4} \mathrm{O}_{12}$ ceramics with different $x$ value as a function of sintering temperature for 1 hour in air.

Typically, 3 wt. $\% \mathrm{MnO}_{2}$-doped $\mathrm{BaNd}_{2} \mathrm{Ti}_{4} \mathrm{O}_{12}$ ceramic sintered at $1300^{\circ} \mathrm{C}$ exhibited compact microstructure and good microwave dielectric properties of $\varepsilon_{r}=90.2$, $Q \times f=5225 \mathrm{GHz}$ and $\tau_{f}=9.7 \mathrm{ppm} \cdot{ }^{\circ} \mathrm{C}^{-1}$. In addition to a relatively low sintering temperature, $\mathrm{BaNd}_{2} \mathrm{Ti}_{4} \mathrm{O}_{12}$ ceramics prepared by $\mathrm{MnO}_{2}$ doping exhibited better and more stable microwave dielectric properties compared with that of pure $\mathrm{BaNd}_{2} \mathrm{Ti}_{4} \mathrm{O}_{12}$ ceramics sintered at high sintering temperature of above $1350^{\circ} \mathrm{C}[4,5]$.

\section{CONCLUSIONS}

The addition of $\mathrm{MnO}_{2}$ reduces the sintering temperature of $\mathrm{BaNd}_{2} \mathrm{Ti}_{4} \mathrm{O}_{12}$ ceramics from $1350^{\circ} \mathrm{C}$ to $1250^{\circ} \mathrm{C}$ with the improvement of microwave dielectric properties. The tungsten-bronze type $\mathrm{BaNd}_{2} \mathrm{Ti}_{4} \mathrm{O}_{12}$ accompanied with a certain amount of $\mathrm{Ba}_{2} \mathrm{Ti}_{9} \mathrm{O}_{20}$ secondary phase was observed at all compositions when samples were sintered at $1300^{\circ} \mathrm{C}$. The lattice constants and cell volumes of $\mathrm{BaNd}_{2} \mathrm{Ti}_{4} \mathrm{O}_{12}$ ceramics kept decreasing with increasing amounts of $\mathrm{MnO}_{2}$, which indicated that the Manganese substituted for $\mathrm{Ti}^{4+}$ in ceramic matrix and led to an shrinkage of the lattice. The changes in microwave dielectric properties were closely related to the trends in the crystal lattice and densification. A similar trend was observed between the relative density and $\varepsilon_{r}$ value. With $\mathrm{x} \leq 2.0 \mathrm{wt}$. $\%$, the $\varepsilon_{r}$ value increased obviously with increasing sintering temperature due to the improvement of densification. Typically, when $\mathrm{x}=4.0 \mathrm{wt}$. $\%$, a high $\varepsilon_{r}$ value of 92.5 for ceramics sintered at $1300^{\circ} \mathrm{C}$ for $1 \mathrm{~h}$ was obtained. But the $Q \times f$ value decreased from 5990 to $4659 \mathrm{GHz}$ with 1 wt. $\% \leq \mathrm{x} \leq 4$ wt. $\%$ due to the progressively deteriorated main phase and the appearance of liquid phase. Finally, the $\tau_{f}$ value increased with increasing $\mathrm{MnO}_{2}$ content. Hence, 3 wt. \% $\mathrm{MnO}_{2}$-doped $\mathrm{BaNd}_{2} \mathrm{Ti}_{4} \mathrm{O}_{12}$ ceramic sintered at $1300^{\circ} \mathrm{C}$ for $1 \mathrm{~h}$ exhibited compact microstructure and good microwave dielectric properties of $\varepsilon_{r}=90.2, Q \times f=5225 \mathrm{GHz}$ and $\tau_{\mathrm{f}}=9.7 \mathrm{ppm} \cdot{ }^{\circ} \mathrm{C}^{-1}$.

\section{Acknowledgments}

This work is supported by National Natural Science Funds of China (Grant No. 51402039).

\section{REFERENCES}

1. Li Y., Li H., Li J., Tang B., Zhang S., Chen H., Wei Y. (2014): Effect of $\mathrm{TiO}_{2}$ Ratio on the Phase and Microwave Dielectric Properties of $\mathrm{Li}_{2} \mathrm{ZnTi}_{3+\mathrm{x}} \mathrm{O}_{8+2 \mathrm{x}}$ Ceramics. Journal of electronic materials, 43(4), 1107-1111. doi:10.1007/ s11664-014-3026-4

2. Chen G.H., Yuan C.L., Zhou C.R., Yang Y. (2013): Lowfiring high permittivity $\mathrm{Ca}_{0.6} \quad \mathrm{Sm}_{0.8 / 3} \quad \mathrm{TiO}_{3}-\left(\mathrm{Li}_{0.5} \mathrm{Nd}_{0.5}\right)$ $\mathrm{TiO}_{3}$ ceramics with $\mathrm{BaCu}\left(\mathrm{B}_{2} \mathrm{O}_{5}\right)$ addition. Ceramics International, 39(8), 9763-9766. doi:10.1016/j.ceramint.2013. 05.028

3. Nenasheva E. A., Kartenko N. F. (2001): High dielectric constant microwave ceramics. Journal of the European Ceramic Society, 21(15), 2697-2701. doi:10.1016/S09552219(01)00348-X

4. Fu Y.P., Liu C. W., Lin C.H., Hsieh C.K. (2005): Effect of $\mathrm{TiO}_{2}$ ratio on $\mathrm{BaO}-\mathrm{Nd}_{2} \mathrm{O}_{3}-\mathrm{TiO}_{2}$ microwave ceramics. Ceramics international, 31(5), 667-670. doi:10.1016/j. ceramint.2004.08.005

5. Wu M.C., Hsieh M.K., Yen C.W., Huang Y.C., Huang W.T., $\mathrm{Su}$ W.F. (2007): Low sintering $\mathrm{BaNd}_{2} \mathrm{Ti}_{4} \mathrm{O}_{12}$ microwave ceramics prepared by $\mathrm{CuO}$ thin layer coated powder. Journal of the European Ceramic Society, 27(8), 28352839. doi:10.1016/j.jeurceramsoc.2006.11.057

6. Huang B., Wang Z., Chen T., Wang L., Fu Z., Zhang Q. (2014): Effects of $\mathrm{MnO}_{2}$ doping on microstructure and microwave dielectric properties of $\mathrm{Ba}_{4.2} \mathrm{Nd}_{9.2} \mathrm{Ti}_{18} \mathrm{O} 54$ $\mathrm{NdAlO}_{3}$ ceramics. Journal of Materials Science: Materials in Electronics, 25(12), 5264-5268. doi:10.1007/s10854014-2299-y 
7. Lin D., Zheng Q., Kwok K. W., Xu, C., Yang C. (2010): Dielectric and piezoelectric properties of $\mathrm{MnO}_{2}$-doped $\mathrm{K}_{0.5} \mathrm{Na}_{0.5} \mathrm{Nb}_{0.92} \mathrm{Sb}_{0.08} \mathrm{O}_{3}$ lead-free ceramics. Journal of Materials Science: Materials in Electronics, 21(7), 649-655. doi:10.1007/s10854-009-9971-7

8. Lee W.H., Su C.Y., Lee Y.C. (2007): Mn-Doped BaO$\left(\mathrm{Nd}_{0.7}, \mathrm{Sm}_{0.3}\right)_{2} \mathrm{O}_{3}-4 \mathrm{TiO}_{2}$ Ceramic Sintered in a Reducing Atmosphere. Japanese journal of applied physics, 46(4R), 1562. doi:10.1143/JJAP.46.1562

9. Varma M.R., Raghunandan R., Sebastian M.T. (2005): Effect of dopants on microwave dielectric properties of $\mathrm{Ba}\left(\mathrm{Zn}_{1 / 3} \mathrm{Ta}_{2 / 3}\right) \mathrm{O}_{3}$ ceramics. Japanese journal of applied physics, 44(1R), 298. doi:10.1143/JJAP.44.298

10. Cai W., Fu C., Gao J., Deng X. (2010): Effect of Mn doping on the dielectric properties of $\mathrm{BaZr}_{0.2} \mathrm{Ti}_{0.8} \mathrm{O}_{3}$ ceramics. Journal of Materials Science: Materials in Electronics, 21(4), 317-325. doi: 10.1007/s10854-009-9913-4

11. Chen X., Zhang W., Bai S. (2013): Effect of $\mathrm{Bi}_{4} \mathrm{~B}_{2} \mathrm{O}_{9}$ addition on the sintering temperature and microwave dielectric properties of $\mathrm{BaO}-\mathrm{Nd}_{2} \mathrm{O}_{3}-4 \mathrm{TiO}_{2}$ ceramics. Journal of Materials Science: Materials in Electronics, 24(1), 224 229. doi:10.1007/s10854-012-0716-7

12. Solomon S., Santha N., Jawahar I.N., Sreemoolanadhan H., Sebastian M.T., Mohanan P. (2000): Tailoring the microwave dielectric properties of $\mathrm{BaRE}_{2} \mathrm{Ti}_{4} \mathrm{O}_{12}$ and $\mathrm{BaRE}_{2} \mathrm{Ti}_{5} \mathrm{O}_{14}$ ceramics by compositional variations. Journal of Materials Science: Materials in Electronics, 11(8), 595602. doi:10.1023/A:1008924611465

13. Laffez P., Desgardin G., Raveau B. (1995): Microwave dielectric properties of doped $\mathrm{Ba}_{6-\mathrm{x}}\left(\mathrm{Sm}_{1-\mathrm{y}} \mathrm{Nd}_{\mathrm{y}}\right)_{8+2 \times / 3} \mathrm{Ti}_{18} \mathrm{O}_{54}$ oxides. Journal of materials science, 30(1), 267-273. doi:10.1007/BF00352161

14. Shannon R.T., Prewitt C.T. (1969): Effective ionic radii in oxides and fluorides. Acta Crystallographica Section B. Structural Crystallography and Crystal Chemistry, 25(5), 925-946. doi:10.1107/S0567740869003220

15. Klotzsche G., Windsch W., Wojcik K. (1993): Electron paramagnetic resonance investigations on manganese doped $\mathrm{PbTiO}_{3}$, ceramics and single crystals. Ferroelectrics Letters Section, 15(5-6), 115-120. doi:10.1080/ 07315179308204247

16. Hu M.Z., Qian J., Gu H.S., Hao Y. D. (2006): Phase formation, sintering behavior and microwave dielectric properties of bismuth and manganese co-doped $[(\mathrm{Pb}, \mathrm{Ca})$ $\mathrm{La}](\mathrm{Fe}, \mathrm{Nb}) \mathrm{O}_{3+\delta}$ solid solution. Journal of materials science, 41(19), 6260-6265. doi:10.1007/s10853-006-0367-2

17. Appel C.C., Bonanos N. (1999): Structural and electrical characterisation of silica-containing yttria-stabilised zirconia. Journal of the European Ceramic Society, 19(6), 847-851. doi:10.1016/S0955-2219(98)00329-X
18. Hakki B.W., Coleman P.D. (1960): A dielectric resonator method of measuring inductive capacities in the millimeter range. Microwave Theory and Techniques, IRE Transactions on, 8(4), 402-410. doi:10.1109/TMTT.1960.1124749

19. Tang B., Fang Z.X., Li H., Liu L., Zhang S.R. (2015): Microwave dielectric properties of $\mathrm{H}_{3} \mathrm{BO}_{3}$-doped $\mathrm{Ca}_{0.61} \mathrm{La}_{0.39} \mathrm{Al}_{0.39} \mathrm{Ti}_{0.61} \mathrm{O}_{3}$ ceramics. Journal of Materials Science: Materials in Electronics, 26(1), 300-306. doi:10.1007/s10854-014-2399-8

20. Liu T., Zhao X.Z., Chen W. (2006): A/B site modified $\mathrm{CaTiO}_{3}$ dielectric ceramics for microwave application. Journal of the American Ceramic Society, 89(3), 1153-1155. doi:10.1111/j.1551-2916.2005.00894.x

21. Zhou D., Pang L.X., Qi Z.M. (2014): Crystal Structure and Microwave Dielectric Behaviors of Ultra-Low-Temperature Fired $\mathrm{x}\left(\mathrm{Ag}_{0.5} \mathrm{Bi}_{0.5}\right) \mathrm{MoO}_{4}-(1-\mathrm{x}) \mathrm{BiVO}_{4}(0.0 \leq x \leq 1.0)$ Solid Solution with Scheelite Structure. Inorganic chemistry, 53(17), 9222-9227. doi:10.1021/ic501306n

22. Fang Z., Tang B., Li Y., Si F., Zhang S. (2015): Microstructures and Microwave Dielectric Properties of $\mathrm{Na}_{0.5} \mathrm{Nd}_{0.2} \mathrm{Sm}_{0.3} \mathrm{Ti}_{1-\mathrm{x}} \mathrm{Sn}_{x} \mathrm{O}_{3}$ Ceramics $(x=0.00$ to 0.50 ). Journal of Electronic Materials, 44(11), 4236-4242. doi:0.1007/s11664-015-3928-9

23. Nomura S., Tomaya K., Kaneta K. (1983): Effect of Mn doping on the dielectric properties of $\mathrm{Ba}_{2} \mathrm{Ti}_{9} \mathrm{O}_{20}$ ceramics at microwave frequency. Japanese Journal of Applied Physics, 22(7R), 1125. doi:10.1143/JJAP.22.1125

24. Yu S., Zhang S., Tang B.,Zhou X., Fang Y. (2012): Microwave dielectric properties of $\mathrm{BaO}-2(1-x) \mathrm{ZnO}-x \mathrm{Nd}_{2} \mathrm{O}_{3}-4 \mathrm{TiO}_{2}$ $(\mathrm{x}=0-1.0)$ ceramics. Ceramics International, 38(1),613-618. doi:10.1016/j.ceramint.2011.07.050

25. Sohn J.H., Inaguma Y., Yoon S.O., Itoh M., Nakamura T., Yoon S.J., Kim H. J. (1994): Microwave dielectric characteristics of ilmenite-type titanates with high Q values. Japanese journal of applied physics, 33(9S), 5466. doi:10.1143/JJAP.33.5466

26. Fang L., Tang Y., Chu D., Zhou H., Zhang H., Chen X., Liu Q. (2012): Effect of $\mathrm{B}_{2} \mathrm{O}_{3}$ addition on the microstructure and microwave dielectric properties of $\mathrm{Li}_{2} \mathrm{CoTi}_{3} \mathrm{O}_{8}$ ceramics. Journal of Materials Science: Materials in Electronics, 23(2), 478-483. doi:10.1007/s10854-011-0421-y

27. Zhou H.F., Wang H., Zhou D., Pang L.X., Yao X. (2008): Effect of $\mathrm{ZnO}$ and $\mathrm{B}_{2} \mathrm{O}_{3}$ on the sintering temperature and microwave dielectric properties of $\mathrm{LiNb}_{0.6} \mathrm{Ti}_{0.5} \mathrm{O}_{3}$ ceramics. Materials Chemistry and Physics, 109(2), 510-514. doi:10.1016/j.matchemphys.2007.12.027

28. Kim J.S., Cheon C.I., Park T.R., Shim H.S. (2000): Dielectric properties and crystal structure of $\mathrm{Ba}_{6-3 x}(\mathrm{Nd}, \mathrm{M})_{8+2 \mathrm{x}} \mathrm{Ti}_{18} \mathrm{O}_{54}$ $(\mathrm{M}=\mathrm{La}, \mathrm{Bi}, \mathrm{Y})$ microwave ceramics. Journal of materials science, 35(6), 1487-1494. doi: 10.1023/A:1004733014635 